DOI: $10.46340 /$ eppd.2021.8.1.20

\author{
Maryna Kalashlinska, PhD in Political Science \\ ORCID ID: https://orcid.org/0000-0001-5825-3631 \\ Maria Curie-Sklodowska University ${ }^{1}$, Lublin, Poland
}

\title{
POLITICAL AND LEGAL ASPECT \\ OF A MULTIDISCIPLINARY APPROACH TO PALLIATIVE AND HOSPICE CARE
}

\author{
Maryna Kalashlinska, PhD \\ Uniwersytet Marii Curie-Skłodowskiej, Lublin, Polska

\section{ASPEKT POLITYCZNO-PRAWNY W MULTIDYSCYPLINARNYM PODEJŚCIU DO OPIEKI PALIATYWNO-HOSPICYJNEJ}

The article deals with the political and legal aspects of a multidisciplinary approach to palliative and hospice care. Palliative care is a part of integrated, human-centered health services at all levels of treatment: it aims to alleviate suffering, whether it is caused by cancer, severe organ failure, drug-resistant tuberculosis, end-stage chronic disease or advanced old age. First of all, we must be aware of the basic goals and tasks of palliative care: adequate relief of pain and other side symptoms of the disease; psychological support for the patient and their relatives; developing an optimal attitude towards death as a natural stage on the human path; meeting the psychological and spiritual needs of the patient and his relatives; offering patients a support system for active life as long as possible; support for the relatives of the patient during the period of illness, as well as during mourning; solving social, legal and ethical problems that arise in connection with a serious illness and the impending death of a person. The author considered the basic concepts in this area and analyzed the political and legal aspect of a multidisciplinary approach to palliative and hospice care. The goal of the palliative care is to prevent suffering and to alleviate the condition of the patient suffering from an incurable disease by active identification of syndromes, like pain, and by providing adequate treatment that will balance the syndromes as much as possible during day and night. The author notes that all people hope for a good life to the very end. But many people feel pain and are suffering at the end of their lives. Public engagement and policy interventions to improve the quality of death through the provision of high quality palliative care have gained momentum in recent years, and some countries have made great strides in improving affordable access to palliative care. Effective palliative care requires a comprehensive, multidisciplinary approach that includes not only medical components (the main part of which is patient symptom control and pain management), but also cultural, social, educational, psychological, political and legal components.

Keywords: palliative care, hospice care, multidisciplinarity, the political aspect of the palliative care, the legal aspect of the palliative care, multidisciplinary team.

Wprowadzenie. Aspekt polityczno-prawny wielodyscyplinarnego podejścia do opieki paliatywnohospicyjnej stanowi jeden z niezwykle ważnych elementów tego obszaru. Opieka paliatywna to podejście poprawiające jakość życia pacjentów (dorosłych i dzieci) oraz ich rodzin borykających się z problemami związanymi z chorobami terminalnymi. Zapobiega cierpieniu i łagodzi je poprzez wczesną identyfikację, prawidłową ocenę i leczenie bólu oraz innych problemów fizycznych, psychospołecznych czy duchowych. Opieka paliatywna jest kluczową częścią zintegrowanych, skoncentrowanych na człowieku usług zdrowotnych na wszystkich poziomach leczenia: ma na celu łagodzenie cierpienia, niezależnie od tego, czy jego przyczyną jest np. rak, poważna niewydolność narządów, lekoodporna gruźlica, schyłkowa choroba przewlekła, wcześniactwo czy zaawansowana starość.

\footnotetext{
${ }^{1}$ Program Stypendialny im. Lane’a Kirklanda 2020/2021
} 
Metody. Badając aspekt polityczno-prawny w multidyscyplinarnym podejściu do opieki paliatywnohospicyjnej zostały wykorzystane przez autora zestaw naukowych metod i technik. Podstawą metodologiczną badań były filozoficzne, ogólno-naukowe metody poznania, a także szczególne metody nauk politycznych i prawnych. W procesie badawczym szeroko wykorzystywano dialektyczną metodę poznania, co w szczególności umożliwiło uwzględnienie opieki paliatywno-hospicyjnej w powiązaniu z polityczno-prawną sferą społeczeństwa. Spośród ogólnonaukowych metod poznania istotne znaczenie miało zastosowanie metod formalno-logicznych i technik przetwarzania informacji: analizy, syntezy, analogii, indukcji, dedukcji, ekstrapolacji, modelowania i abstrakcji. Ich wykorzystanie w badaniu teoretycznych i prawnych podstaw badania problemów kształtowania systemu opieki paliatywnej.

Wyniki. Skuteczna opieka paliatywno-hospicyjna obejmuje dbałość o kondycję fizyczną, zdolności umysłowe i stan psychiczny chorego, a także wspieranie jego rodziny. Taka opieka wymaga wszechstronnego, multidyscyplinarnego podejścia, które obejmuje nie tylko elementy medyczne (ich główną częścią jest kontrola objawów, na które cierpi pacjent i leczenie bólu), ale także psychologiczne, prawne, społeczne, edukacyjne, kulturowe. Opieka tego typu powinna uwzględniać zaangażowanie rodziny i np. wolontariuszy.

Przede wszystkim musimy mieć świadomość podstawowych celów i zadań opieki paliatywnej są to ${ }^{1}$ :

- odpowiednie łagodzenie bólu oraz innych ,ubocznych objawów choroby;

- wsparcie psychologiczne pacjenta i opiekujących się nim bliskich;

- rozwijanie optymalnej postawy wobec śmierci jako naturalnego etapu na drodze człowieka ;

-zaspokajanie psychologicznych i duchowych potrzeb pacjenta i bliskich mu osób;

- oferowanie pacjentom system wsparcia, aby mogli żyć aktywnie tak długo jak to możliwe;

- wsparcia dla bliskich pacjenta w okresie choroby, a także w czasie żałoby;

- rozwiązywanie problemów społecznych i prawnych, etycznych, które pojawiają się w związku z poważną chorobą i zbliżającą się śmiercią człowieka.

Praca zespołowa jest uważana za podstawę opieki paliatywnej. Chociaż opieka paliatywna może być wykonywana $\mathrm{w}$ praktyce przez jedną osobę, to praca grupowa w opiece paliatywnej jest najbardziej efektywna. Opieka paliatywna powinna być świadczona w sposób wieloprofesjonalny i interdyscyplinarny. Zespół składa się z ludzi z różnych specjalności i dyscyplin klinicznych, którzy współpracują w celu zapewnienia opieki nad pacjentem i / lub poprawy jakości jego życia. Skład zespołu może się różnić w zależności od wielu czynników. Aby rozwiązać złożone problemy specjalistycznej opieki paliatywnej, konieczna jest współpraca przedstawicieli różnych zawodów i dyscyplin w celu zagwarantowania pacjentowi pomocy medycznej, wsparcia psychologicznego, społecznego, prawnego i duchowego.

Praca takiego „teamu” jest niezbędna dla skutecznej opieki paliatywnej, w której komunikacja odbywa się w trzech głównych obszarach:

1. komunikacja w zespole hospicyjnym;

2. komunikacja z placówkami medycznymi, w tym świadczącymi opiekę paliatywną;

3. komunikacja z samym pacjentem i bliskimi.

Wszystkie te poziomy komunikacji mają na celu zapewnienie wysokiego poziomu jakości opieki paliatywnej, co wymaga połączenia opieki medycznej, która obejmuje leczenie bólu, opiekę i leczenie objawów oraz niezbędne wsparcie społeczne, psychologiczne i duszpasterskie dla pacjentów i ich bliskich.

Rada Europy $^{2}$ i Krajowa Komisja Ekspertów Opieki Paliatywnej ${ }^{3}$ formułują szczegółowe wymagania dla personelu specjalistycznego w zakresie opieki paliatywnej. Zgodnie z wytycznymi oprócz pielęgniarek i lekarzy pożądane jest, aby w skład zespołu wchodzili tacy specjaliści (na stałe lub w niepełnym wymiarze godzin) jak:

- pracownicy socjalni;

- specjaliści posiadający umiejętności psychospołeczne /socjoterapeuci;

- pracownicy administracyjni;

- fizjoterapeuci;

- profesjonaliści posiadający umiejętności do pracy z ludźmi w żałobie;

- koordynatorzy w zakresie pomocy duchowej /duszpasterze/ ;

\footnotetext{
${ }^{1}$ WHO (2021). Palliative care $<$ https://www.who.int/health-topics/palliative-care/> (2021, styczeń, 27).

${ }^{2} \mathrm{COE}$ (2003). Recommendation Rec 24 of the Committee of Ministers to member states on the organisation of palliative care $<$ www.coe.int $/ \mathrm{t} / \mathrm{dg} 3 /$ health/Source/Rec(2003)24_en.pdf $>$ (2021, styczeń, 27).

${ }^{3}$ National Health Library \& Knowledge Service (2001). Report on the National Advisory Committee on Palliative Care. Department of Health and Children $<\mathrm{http} / /$ hdl.handle.net/10147/43031> (2021, styczeń, 27).
} 
- koordynatorzy wolontariatu;

- specjaliści od leczenia ran;

- specjaliści ds. postępowania z pacjentami z obrzękiem limfatycznym;

- terapeuci zajęciowi;

- logopedzi;

- dietetycy;

- farmaceuci;

- specjaliści medycyny komplementarnej / tradycyjnej;

- trenerzy / instruktorzy;

- bibliotekarze.

Podstawowy zespół opieki paliatywnej powinien składać się przynajmniej z przeszkolonych pielęgniarek i lekarzy; jeśli to możliwe, do zespołu włączani są psychologowie, pracownicy socjalni i fizjoterapeuci. W skład podstawowego zespołu mogą wchodzić inni specjaliści, ale częściej są oni zaangażowani w razie potrzeby.

Badając kwestie odpowiedniego łagodzenia bólu i innych podobnych objawów, podkreślamy, że ból według definicji Międzynarodowego Towarzystwa Badania Bólu [International Association for the Study of Pain $^{1}$ - jest to subiektywnie przykre i negatywne wrażenie zmysłowe i emocjonalne, powstające pod wpływem bodźców (tzw. nocyceptywnych: nocyceptory są receptorami bólowymi) uszkadzających tkankę lub zagrażającymi jej uszkodzeniu. Ból jest odczuciem subiektywnym, dlatego jest nim wszystko to, co chory w ten sposób nazywa, bez względu na obiektywne objawy z nim związane. Ból ma istotne znaczenie dla rozpoznania i umiejscowienia procesu chorobowego oraz uniknięcia lub zminimalizowania uszkodzenia tkanki.

Pozbawienie człowieka właściwego postępowania przeciwbólowego jest traktowaniem nieludzkim. Zgodnie ze stanowiskiem Europejskiego Trybunału Praw Człowieka Rady Europy postępowanie powodujące poważne cierpienia fizyczne i psychiczne, mieści się w kategorii nieludzkiego traktowania, natomiast brak stosowania odpowiedniego leczenia przeciwbólowego, które jest konieczne ze względu na proces chorobowy, narusza ludzką godność i może być interpretowane jako poniżające traktowanie w rozumieniu art. 3 Konwencji o Ochronie Prawa Człowieka i Podstawowych Wolności z 1950 roku [Konwencja o Ochronie Praw Człowieka i Podstawowych Wolności sporządzona w Rzymie dnia 4 listopada $1950^{2}$.

Częstokroć ból, którego doświadczamy w życiu jest ostrym (krótkotrwałym), ale odgrywa ważną rolę sygnalizuje pewien problem zdrowotny, pozwala $\mathrm{w}$ porę zwrócić się o odpowiednią pomoc, a przy skutecznym leczeniu ból ustępuje i następuje powrót do zdrowia. Większość pacjentów paliatywnych w terminalnym stadium choroby odczuwa ból, który ani nie jest ostry ani krótkotrwały oraz nie pełni funkcji ochronnej. Te dolegliwości są częściej chroniczne, są bezużyteczne, ponieważ, nie dostarczają nowych informacji, które pomogą zlikwidować ich przyczynę, ten ból z czasem tylko się nasila.

Zgodnie z definicją Międzynarodowego Stowarzyszenia Badań nad Bólem (IASP), ból przewlekły to ból, który utrzymuje się dłużej niż 3 miesiące bez wyeliminowania przyczyny [Ból. Polskie Towarzystwo Badania Bólu ${ }^{3}$.

„Przewlekły zespół bólowy” jest niezależną chorobą, dodatkowo obciążającą życie pacjenta i jego otoczenia, stanowi poważny problem medyczny i społeczny, często uruchamia złożony pakiet fizycznych i psychospołecznych zmian, które są integralną częścią problemu bólu przewlekłego i znacznie obciążają pacjenta, a do których należą: unieruchomienie i w konsekwencji osłabienie mięśni i stawów;

- obniżenie odporności i podwyższenie podatności na choroby; zaburzenia snu;

- problemy z apetytem i odżywianiem; uzależnienie od leków; nadmierną zależność od rodziny i innych opiekunów; nadużywanie oraz niewłaściwe wykorzystywanie profesjonalnego systemu opieki zdrowotnej; złą wydajność w pracy lub niezdolność do pracy, upośledzenie; izolację od otoczenia i rodziny, zamykanie się w sobie; lęk, strach; rozgoryczenie, frustrację, depresję, tendencje samobójcze [EFIC w sprawie bólu. Deklaracja Europejskiej Federacji Oddziałów IASP odnośnie bólu przewlekłego jako głównego problemu zdrowotnego, traktowanego jako „choroba sama w sobie”4.

\footnotetext{
${ }^{1}$ International Association for the Study of Pain (2021). Homepage <www.iasp-pain.org> (2021, styczeń, 27).

${ }^{2}$ Internetowy System Aktów Prawnych (1950). Konwencja o Ochronie Praw Człowieka i Podstawowych Wolności sporzadzona $w$ Rzymie <http://isap.sejm.gov.pl/isap.nsf/DocDetails.xsp?id=WDU19930610284> (2021, styczeń, 27).

${ }^{3}$ Polskie Towarzystwo Badania Bólu (2021). Ból <https://ptbb.pl/bol> (2021, styczeń, 27).

${ }^{4}$ Polskie Towarzystwo Badania Bólu (2021). EFIC w sprawie bólu. Deklaracja Europejskiej Federacji Oddziałów IASP odnośnie bólu przewlekłego jako głównego problemu zdrowotnego, traktowanego jako „, choroba sama w sobie” $<$ https://ptbb.pl/bol/115-deklaracja-efic-w-sprawie-bolu> (2021, styczeń, 27).
} 
Rozpoznawanie i leczenie przewlekłego bólu jest niezwykle ważne dla pacjentów, otrzymujących opiekę paliatywną. System uśmierzania różni się od leczenia ostrego, odwracalnego bólu. Aby dobrać odpowiednią terapię, należy najpierw określić rodzaj bólu co jest podstawa jego kontroli.

Światowe standardy leczenia bólu przewlekłego to regularne stosowanie silniejszych leków, gdy słabsze leki przestają być skuteczne, oraz dobór różnych leków przeciwbólowych zgodnie ze schematem Światowej Organizacji Zdrowia ${ }^{1}$-która w 1986 r. wprowadziła tzw. "Drabinę analgetyczną", czyli schemat farmakologicznego leczenia bólu. Szczególnie odnosi się to do przewlekłego bólu w chorobach nowotworowych. Drabina analgetyczna wymaga dokładnej oceny i interpretacji natężenia bólu.

Drabina analgetyczna to trzystopniowy schemat leczenia bólu. Leczenie zaczyna się od stopnia pierwszego. Jeśli ból się utrzymuje lub wzrasta mimo stosowanych leków, przechodzi się na wyższy stopień drabiny.

Leczenie bólu przewlekłego musi obejmować dwa główne równoległe elementy:

1. Stosowanie leków przeciwbólowych. Rodzaj i dawki leków dobierane są indywidualnie, w zależności od nasilenia bólu - według drabiny analgetycznej (leki nieopioidowe, opioidy).

2. Stosowanie leków adjuwantowych (koanalgetyków) i uzupełniających metod leczenia (blokady, neurolizy, paliatywne leczenie onkologiczne).

Wybór leku (leków) lub metody leczenia zależy przede wszystkim od ustalonego rozpoznania rodzaju i natężenia bólu.

Wsparcie psychologiczne pacjenta i opiekujących się nim bliskich. Nieuleczalna choroba w istotny sposób zakłóca życie pacjenta: oczekiwania na diagnozę, poprzez bardzo uciążliwe etapy leczenia i utratę nadziei na wyzdrowienie. Wszystkie te czynniki zaburzają równowagę psychiczną wielu pacjentów, co przejawia się zwłaszcza nasileniem negatywnych reakcji emocjonalnych: lęku, depresji, gniewu itp. Jest to bardzo dyskomfortowy stan dla pacjenta znacznie obniżający jego samopoczucie i jakość życia. Dlatego pacjent zaczyna się bronić i stara się przywrócić równowagę: aktywuje różnego rodzaju strategie obronne, szuka wsparcia itp. Poza tym w przebiegu choroby i leczenia dochodzi niekiedy do uszkodzenia ośrodkowego układu nerwowego, czyli do tak zwanych organicznych zaburzeń psychicznych.

Duchowość odnosi się do wartości życia człowieka i jest związana z osobistym poszukiwaniem jego sensu i znaczenia. To uniwersalna koncepcja, która nie zawsze jest kojarzona $\mathrm{z}$ religią, ale dla wielu pacjentów religia i wiara w Boga może pełnić rolę przewodnika w tym poszukiwaniu. Ogromną rolę w tych aspektach opieki paliatywnej odgrywają psychologowie, psychoonkolodzy, socjoterapeuci, księża oraz wolontariusze, którzy przeszli specjalistyczne szkolenie w zakresie pomocy umierającym pacjentom i ich rodzinom. Jedną z głównych zasad multidyscyplinarnej opieki paliatywnej jest wyznawanie postawy wobec śmierci jako naturalnego etapu na drodze człowieka, które nie stara się ani przyspieszać ani odraczać momentu śmierci.

Organizując system opieki paliatywnej, należy również pamiętać o problemach, z którymi borykają się członkowie najbliższej rodziny nieuleczalnie chorego pacjenta. Dobrze zarządzana opieka paliatywna może wiele zdziałać, łagodząc cierpienie pacjenta i rodziny podczas ostatniego okresu umierania . Członkowie rodziny na zawsze zapamiętają nie tylko trudne, ale i lepsze chwile związane z ostatnimi dniami życia ukochanej osoby, co pomoże łatwiej poradzić sobie ze stratą.

Zestawienie głównych problemów, z którymi najczęściej boryka się rodzina pacjenta obejmuje²:

- problemy ze zdrowiem psychicznym: depresja, lęk, subkliniczny stres, cierpienie, ambiwalencja (niespójność) opieki, samoizolacja, wysoki poziom negatywnych skutków, w tym poczucie winy, strach, lęk, smutek;

- problemy ze zdrowiem fizycznym: zmęczenie, pogorszenie ogólnego stanu funkcjonalnego, pojawienie się chorób somatycznych i zaostrzenie przewlekłych, zwiększona podatność na urazy domowe, problemy ze snem;

- problemy społeczne: ograniczone możliwości zatrudnienia, trudności finansowe, często nierozwiązane kwestie mieszkaniowe (złe warunki życia, brak windy i rampy, nieodpowiednia wielkość lokalu), deficyt czasu na samodzielną opiekę, obniżona jakość życia oraz izolacja od społeczeństwa;

- problemy rodzinne, problemy behawioralne, konflikty małżeńskie.

\footnotetext{
${ }^{1}$ WHO (1996). Guidelines: Cancer Pain relief $<$ http://whqlibdoc.who.int/publications/9241544821.pdf $>$ (2021, styczeń, 27).

${ }^{2}$ Higginson, I. Evidence-based palliative care. Journal of the European Association of palliative care,1999, 6, 6

(Nov/Dec), s. 190
} 


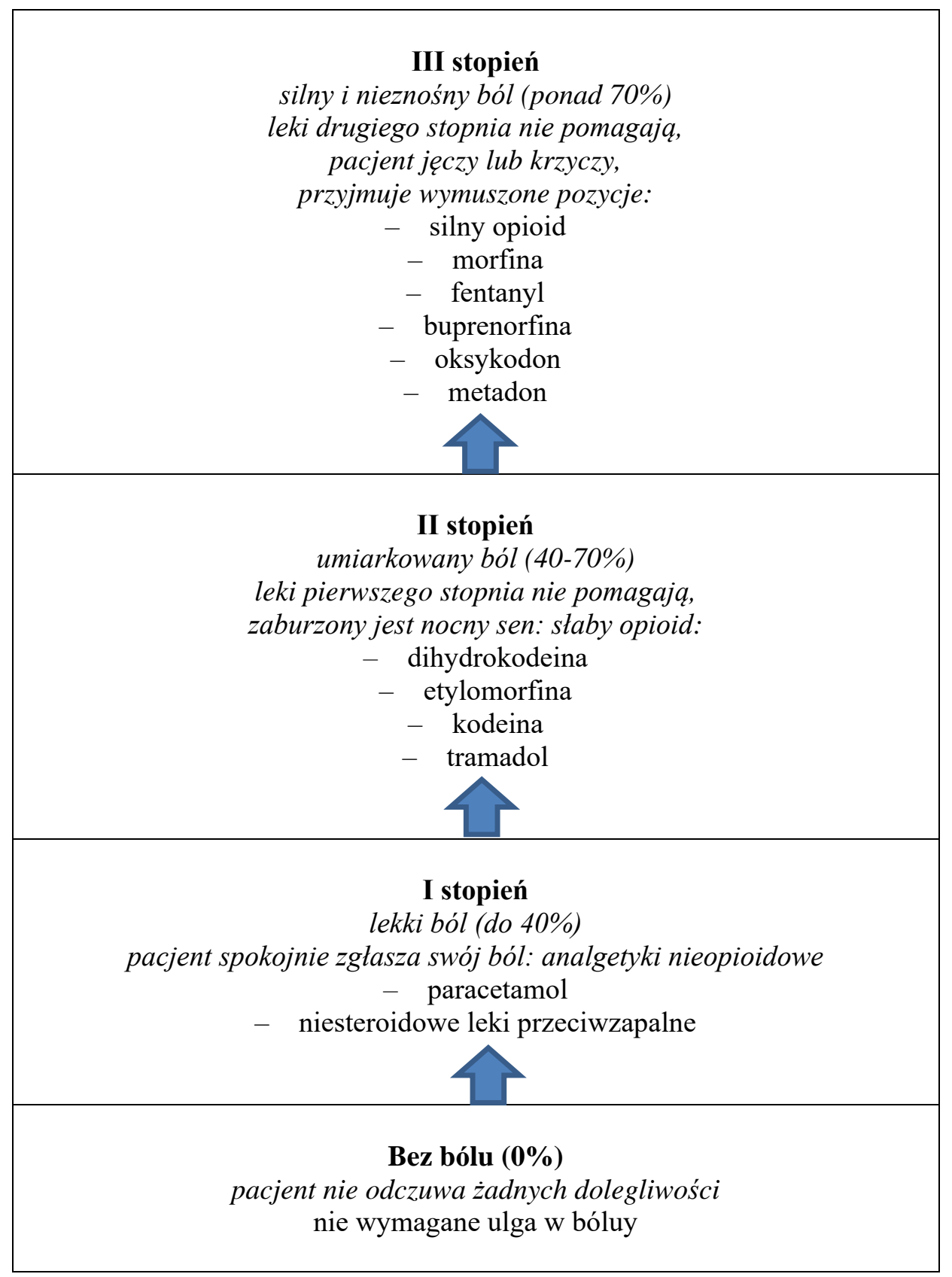

\section{Ryc. 1. Drabina analgetyczna Światowej Organizacji Zdrowia ${ }^{1}$}

Dlatego zarówno w okresie choroby, jak i żałoby należy pamiętać o wsparciu bliskich osoby umierającej w rozwiązywaniu problemów psychologicznych, społecznych, prawnych i etycznych wynikających $\mathrm{z}$ choroby i śmierci chorego. Skuteczna opieka paliatywno-hospicyjna wymaga wszechstronnego multidyscyplinarnego podejścia, które obejmuje nie tylko elementy medyczne (kontrola objawów pacjenta), ale także psychologiczne, prawne,społeczne, edukacyjne, kulturowe ,opieka powinna także opierać się na zaangażowaniu rodziny w okresie choroby pacjenta, żałoby.

Podziękowania i dyskusja. Podziękowania dla Programu Stypendialnogo im. Lane'a Kirklanda 2020/2021 i University Marii Curie-Skłodowskiej w Lubline za organizacyjne, naukowe i finansowe wsparcie moich badań. W kolejnych badaniach zapraszamy do omówienia aspektów etycznych opieki paliatywno-hospicyjnej.

\footnotetext{
${ }^{1}$ Ibid.
} 


\section{References:}

1. WHO (2021). Palliative care $<$ https://www.who.int/health-topics/palliative-care/ $>$ (2021, January, 27). [in English].

2. COE (2003). Recommendation Rec 24 of the Committee of Ministers to member states on the organisation of palliative care $<$ www.coe.int/t/dg3/health/Source/Rec(2003)24_en.pdf $>$ (2021, January, 27). [in English].

3. National Health Library \& Knowledge Service (2001). Report on the National Advisory Committee on Palliative Care. Department of Health and Children $<\mathrm{http} / /$ hdl.handle.net/10147/43031> (2021, January, 27). [in English].

4. International Association for the Study of Pain (2021). Homepage <www.iasp-pain.org $>$ (2021, January, 27). [in English].

5. Internetowy System Aktów Prawnych (1950) [Internet System of Legal Acts (1950)]. Konwencja o Ochronie Praw Człowieka i Podstawowych Wolności sporządzona w Rzymie [Convention for the Protection of Human Rights and Fundamental Freedoms drawn up in Rome]

$<$ http://isap.sejm.gov.pl/isap.nsf/DocDetails.xsp?id=WDU19930610284> (2021, January, 27). [in Polish].

6. Polskie Towarzystwo Badania Bólu (2021) [Polish Society for the Study of Pain (2021)]. Ból [Pain] $<$ https://ptbb.pl/bol $>$ (2021, January, 27). [in Polish].

7. Polskie Towarzystwo Badania Bólu (2021) [Polish Society for the Study of Pain (2021)]. EFIC w sprawie bólu. Deklaracja Europejskiej Federacji Oddziałów IASP odnośnie bólu przewlekłego jako głównego problemu zdrowotnego, traktowanego jako „choroba sama w sobie” [EFIC on pain. Declaration of the European Federation of Branches of the IASP on chronic pain as a major health problem, treated as "a disease in itself"] $<$ https://ptbb.pl/bol/115-deklaracja-efic-w-sprawie-bolu> (2021, January, 27). [in Polish].

8. WHO (1996). Guidelines: Cancer Pain relief $<$ http://whqlibdoc.who.int/publications/9241544821.pdf $>$ (2021, January, 27). [in English]. 